\title{
Vermicompost and Sewage Sludge-Based Substrates as Alternative for the Forest Seedlings Production
}

\author{
Solimar José da Silva \\ Universidade Federal Rural do Rio de Janeiro, Rodovia BR 465, Km 07, Seropédica - \\ RJ, Brazil \\ E-mail: solimarjose@yahoo.com.br
}

João Paulo Francisco (Corresponding author)

Universidade Estadual de Maringá, Estrada Paca - Jardim São Cristóvão, Umuarama - PR, Brazil

Tel: + $5527996353862 \quad$ E-mail:jpfrancisco2@uem.br

Fabiana da Costa Barros

Universidade Federal Rural do Rio de Janeiro, Rodovia BR 465, Km 07, Seropédica - RJ, Brazil

E-mail: faby.barros@hotmail.com

Bruno Patias Lena

State University of the Midwest, campus CEDETEG in Guarapuava, Agronomy of

Departament

E-mail: brunoplena@gmail.com

Alexandre Lioi Nascentes

Universidade Federal Rural do Rio de Janeiro, Rodovia BR 465, Km 07, Seropédica - RJ, Brazil

E-mail: alexandrelioi@gmail.com 
Ana Daniela Lopes

Universidade Paranaense - Programa de Pós-Graduação em Biotecnologia Aplicada à Agricultura, Praça Mascarenhas de Moraes, 4282 - Centro, Umuarama-Paraná, Brazil

E-mail: anadanielalopes@ prof.unipar.br

\title{
Leonardo Duarte Batista da Silva
}

Universidade Federal Rural do Rio de Janeiro, Rodovia BR 465, Km 07, Seropédica - RJ, Brazil

E-mail: monitoreambiental@gmail.com

Received: Oct. 27, 2019

doi:10.5296/jas.v8i2.15715
Accepted: Dec. 2, 2019

Published: Dec. 23, 2019

URL: https://doi.org/10.5296/jas.v8i2.15715

\begin{abstract}
The partial or total use of organic compounds for forest seedling production has been considered a reliable alternative to commercial substrate. The objective of this study was to investigate the red-angico (Anadenanthera macrocarpa) and pink kapok (Chorisia speciosa) seedlings development performance cultivated with different proportion of commercial substrate mixed with vermicompost or sewage sludge. Seedlings were produced under greenhouse conditions and different commercial substrate mixed proportions with vermicompost and sewage sludge at 0 (only commercial substrate), 25, 50,75, and $100 \%$ (only organic compound) were evaluated. An increment of plant height and steam diameter for red-angico and pink kapok were observed when both vermicompost or sewage sludge were added to the substrate. Best seedlings development results were found when organic compound represented from $50-75 \%$ of the substrate. The use of vermicompost and sewage sludge have showed a good alternative to the commercial substrate.
\end{abstract}

Keywords: anadenanthera macrocarpa, chorisia speciosa, organic compound

\section{Introduction}

The use of substrate for forest seedling production has been highlighted by its efficiency. However, since there are different feedstocks available that can be used to formulate the substrate, information about the best substrate formula for high forest seedling production is still lacking. According to, an ideal substrate should present chemical/physical characteristics that lead to both high production and quality seedlings, as well as being free from pests and diseases. The authors also highlight the need for new research that evaluates different substrate characteristics on the forest species seedling production. 
Vermicompost and sewage sludge are two components that are commonly used to produce formulated substrate for forest seedling production. The vermicompost is an organic substance resulting from worms' biological activities, which leads to higher nutrient bioavailability due to the high microbial activity. The sewage sludge is a solid sub product from sewage treatment plants that is capable of promoting selected nutrient availability to the seedling, as well as to contribute to the reduction of the environmental pollution by its adequate final usage (Santos $e t$ al., 2014a).

The amount of studies that investigate the effect of vermicompost or sewage sludge mixture (partial or total) with commercial substrate for forest seedling production have increased in the last years. (Rocha et al., 2013) found that the treatment with carbonized rice husk-based commercial substrate mixed with sewage sludge presented better eucalyptus seedling plant height and stem diameter results when compared to the treatment with only commercial substrate. With the objective of investigating eucalyptus seedling development under different proportions of cattle manure-based vermicompost and commercial substrate, (Silva et al., 2017) found similar seedling development indexes for the substrate with 20 and $40 \%$ of vermicompost mixture compared to the treatment cultivated under $100 \%$ commercial substrate. Moreover, other studies have shown better forest seedling production when different organic compounds where mixed with commercial substrate. (Chaves et al., 2006) found high red-angico (Anadenanthera macrocarpa) seedling production when cultivated with sifted sugarcane bagasse and filter cake-based substrate. Good red-angico seedling production was also found by (Uliana et al., 2014) using substrate with sugarcane bagasse decomposed with humus. High seedling production for eucalyptus was also found when cultivated with substrate based on residue from paper and cellulose production (Toledo et al al., 2015), and on sewage sludge biochar (Gonzaga et al., 2018).

Reliable results about the red-angico and pink kapok (Chorisia speciosa) seedling production performance cultivated with vermicompost or sewage sludge-based substrate are still lacking. Thus, identifying the best organic compound to commercial substrate ratio for forest seedling production is an invaluable information for the decision-making. Recently, Silva et al. (2017a) observed better seedling plant height and stem diameter indexes for red-angico cultivated with vermicompost when compared to vermiculite, showing promising results of this organic compound for red-angico seedling production.

This study had the objective of evaluating the red-angico and pink kapok seedling development cultivated under commercial substrate mixed with different proportion of vermicompost or sewage sludge.

\section{Material and Methods}

The experiment was carried out at the Instituto de Florestas da Universidade Federal Rural do Rio de Janeiro forest nursery, located at Seropédica-RJ $\left(22.7472^{\circ} \mathrm{S}, 43.6996^{\circ} \mathrm{W}\right)$. The experimental area is at $33 \mathrm{~m}$ from see level, presents mean annual temperature of $22,7^{\circ} \mathrm{C}$, and accumulated annual mean precipitation of 1291,7 mm (Carvalho et al., 2006). The climate is subhumid tropical with low or without water deficit and mesothermic with well distributed heat among the year (Aw), according to the Köppen classification (Peel et al., 2007). 
A shadehouse with $10 \mathrm{~m}$ width and $17 \mathrm{~m}$ length was used for the experiment and both roof and walls were covered by a $70 \%$ light interception shade cloth. A low-density plastic film $(0,91 \mathrm{~g} \mathrm{~cm}-3)$ was added above the shade cloth of the roof to avoid direct rainfall interference. Two native species from Atlantic Forest were selected for seedlings production: red-angico (Anadenanthera macrocarpa) and pink kapok (Chorisia speciosa). All seedlings were irrigated by an automated microsprinkler irrigation system with $169 \mathrm{~L} \mathrm{~h}^{-1}$ flow and irrigation was performed twice a day for five minutes each. Polypropylene pods with $250 \mathrm{~cm}^{3}$ were used for the seedling's cultivation, and trays containing 54 slots were used to accommodate the pods.

The vermicompost was produced in a masonry bed with $6 \mathrm{~m}$ length, $1 \mathrm{~m}$ width, and $0,5 \mathrm{~m}$ height. A $70 \%$ sunlight interception shade cloth was used to cover the entire bed. The shade cloth had the objectives of improving worm development by protecting from direct sunlight that could interfere on the worm's development due to the high temperature, as well as reducing the weed infestation, and avoiding bird attack to the worms. Cattle manure provided by the Sistema Integrado de Produção Agroecológica (SIPA) which belongs to Embrapa Agrobiologia were used as main feedstock for the vermicompost production. Red Californian earthworm (Eisenia foetida) specie were used for the vermicompost production, and it presents some beneficial characteristics such as rapid proliferation and high survival and adaptability in captivity conditions (Aquino, A. M.; Oliveira, A. M. G.; Loureiro, 2005).

After reached ambient temperature (at shadow), a uniform $30 \mathrm{~cm}$ thickness layer of cattle manure was distributed into the masonry bed. Further, a density of 1000 worms per $\mathrm{m}^{3}$ of Red Californian earthworm were spread on the cattle manure surface, as suggested by (Aquino, A. M.; Oliveira, A. M. G.; Loureiro, 2005). The vermicompost moisture were monitored and kept close to $60 \%$, reaching the stabilization 45-50 days after the worms' decomposition.

The worms were removed from the vermicompost by adding fresh cattle manure baits followed by $2 \mathrm{~mm}$ soil sifter. Then, the vermicompost was put into transparent plastic bags and kept at direct sunlight for 15 days to guarantee the complete solarization. Additionally, $15 \%$ of fine charcoal and 2\% castor cake were added to the vermicompost (Oliveira, 2011). The fine charcoal was obtained by certified wood company that uses legal reforestation wood that is located at Itaguaí-RJ. The fine charcoal was sieved to obtain particles ranging from 3-5 mm prior mixing with the vermicompost.

The sewage sludge was collected from the Alegria-RJ household wastewater sewage treatment plant. No chemical or biological treatment with the sewage sludge was performed, so its original composition was used in this study.

Both the vermicompost and the sewage sludge were mixed with commercial substrate to obtain the following ratio: $100 \%$ commercial substrate (C100); $25 \%$ vermicompost volume percentage (V25); 50\% vermicompost volume percentage (V50); 75\% vermicompost volume percentage (V75); 100\% vermicompost volume percentage (V100); 25\% sewage sludge volume percentage (S25); 50\% sewage sludge volume percentage (S50); 75\% sewage sludge volume percentage (S75); and 100\% sewage sludge volume percentage (S100). Tables 1 and 2 show the chemical and heavy metal concentration for the sewage sludge used respectively. It is important to mention that the sewage sludge usage for any agriculture activity in Brazil must 
meet the Brasil (2006) regulation, which defines the maximum level of contaminants within its composition.

Table 1. Substrate chemical concentration for commercial (C), and for every vermicompost (V) and sewage sludge $(\mathrm{S})$ proportion used for red-angico and pink kapok seedling production

\begin{tabular}{|c|c|c|c|c|c|c|c|c|c|c|c|}
\hline Substrate & $\mathrm{pH}$ & $\begin{array}{c}\mathrm{P} \\
\cdots \cdot \mathrm{mg} \mathrm{d}\end{array}$ & $\begin{array}{c}\mathrm{K} \\
\mathrm{n}^{-3} \cdots\end{array}$ & $\begin{array}{c}\mathrm{Ca}^{2+} \\
\mathrm{cmol}_{\mathrm{c}} \mathrm{dm}^{-3}\end{array}$ & $\begin{array}{l}\text { Ntotal } \\
\text { dag } \mathrm{kg}^{-1}\end{array}$ & $\begin{array}{l}\mathrm{Mg}^{2+} \\
\cdots \cdots \cdot \mathrm{c}\end{array}$ & $\begin{array}{l}\mathrm{Al}^{3+} \\
\mathrm{ol}_{\mathrm{c}} \mathrm{dm}\end{array}$ & $\mathrm{H}+\mathrm{Al}$ & $\begin{array}{l}\mathrm{EB} \\
\%\end{array}$ & $\begin{array}{l}\text { BS } \\
\%\end{array}$ & $\begin{array}{c}\mathrm{OM} \\
\text { dag } \mathrm{kg}^{-1}\end{array}$ \\
\hline $\mathrm{C} 100$ & 5.2 & 528.7 & 462 & 5.7 & 0.18 & 2.9 & 0.1 & 5.0 & 9.8 & 66.1 & 27.6 \\
\hline V25 & 5.7 & 745.9 & 1249 & 6.5 & 0.15 & 5.3 & 0.1 & 4.0 & 15.0 & 78.9 & 25.0 \\
\hline V50 & 6.3 & 734.3 & 1369 & 6.0 & 0.18 & 7.1 & 0.0 & 4.1 & 16.6 & 80.2 & 22.5 \\
\hline V75 & 7.6 & 1322.7 & 3818 & 8.0 & 0.21 & 11.1 & 0.0 & 4.0 & 28.9 & 87.8 & 31.1 \\
\hline V100 & 7.0 & 4704.8 & 3754 & 8.1 & 0.21 & 12.7 & 0.1 & 2.1 & 30.4 & 93.5 & 27.6 \\
\hline S25 & 4.1 & 651.2 & 362 & 10.4 & 0.15 & 3.9 & 0.1 & 9.7 & 15.4 & 61.2 & 26.0 \\
\hline S50 & 4.7 & 725.1 & 302 & 13.0 & 0.15 & 4.4 & 0.1 & 9.7 & 18.2 & 65.2 & 28.8 \\
\hline S75 & 4.7 & 558.8 & 161 & 15.3 & 0.18 & 4.7 & 0.1 & 9.9 & 20.4 & 67.4 & 27.9 \\
\hline $\mathrm{S} 100$ & 5.7 & 1058.2 & 83 & 12.1 & 0.14 & 3.8 & 0.0 & 5.0 & 16.1 & 76.3 & 31.5 \\
\hline
\end{tabular}

* $\mathrm{pH}$ - $\mathrm{pH}$ in $\mathrm{H} 2 \mathrm{O} ; \mathrm{P}$ - phosphor; $\mathrm{K}$ - potassium; $\mathrm{Ca}^{2+}$ - calcium; Ntotal - total nitrogen; $\mathrm{Mg}^{2+}$ magnesium; $\mathrm{Al}^{3+}$ - aluminum; $\mathrm{H}+\mathrm{Al}$ - exchangeable aluminum; $\mathrm{EB}$ - exchangeable base; $\mathrm{BS}$ percent base saturation; OM - organic matter. 
Table 2. Substrate heavy metal concentration for commercial (C), and for every vermicompost (V) and sewage sludge (S) proportion used for red-angico and pink kapok seedling production

\begin{tabular}{ccccccccc}
\hline & $\mathrm{Zn}$ & $\mathrm{Fe}$ & $\mathrm{Mn}$ & $\mathrm{Cu}$ & $\mathrm{Cd}$ & $\mathrm{Pb}$ & $\mathrm{Ni}$ & $\mathrm{Cr}$ \\
\cline { 2 - 8 } Substrate & & & \multicolumn{7}{c}{$\mathrm{mg} \mathrm{dm}^{-3}$} \\
C100 & 6.4 & 163.6 & 39.7 & 0.91 & 1.020 & 0.360 & 1.240 & 0.500 \\
V25 & 18.2 & 116.1 & 79.2 & 0.61 & 0.980 & 0.460 & 0.980 & 0.530 \\
V50 & 21.8 & 90.8 & 97.2 & 0.58 & 1.050 & 0.610 & 0.880 & 0.700 \\
V75 & 39.2 & 46.5 & 198.9 & 0.54 & 0.800 & 0.670 & 0.550 & 0.640 \\
V100 & 47.7 & 16.8 & 243.8 & 0.54 & 1.170 & 1.000 & 0.460 & 0.460 \\
S25 & 84.3 & 259.9 & 39.8 & 5.76 & 1.260 & 0.320 & 1.270 & 0.500 \\
S50 & 141.1 & 323.8 & 43.6 & 8.76 & 1.140 & 0.550 & 0.480 & 0.470 \\
S75 & 180.1 & 382.6 & 49.5 & 14.67 & 0.980 & 0.800 & 0.630 & 0.440 \\
S100 & 238.9 & 651.4 & 58.6 & 22.12 & 1.050 & 0.540 & 1.840 & 0.590 \\
\hline
\end{tabular}

* $\mathrm{Zn}$ - zinc; $\mathrm{Fe}$ - iron; $\mathrm{Mn}$ - manganese; $\mathrm{Cu}$ - copper; $\mathrm{Cd}$ - cadmium; $\mathrm{Pb}$ - lead; $\mathrm{Ni}$ - nickel; $\mathrm{Cr}$ - chrome.

Each proportion of vermicompost or sewage sludge with commercial substrate was cultivated with both red-angico and pink kapok. Seedling occurred on November 22nd, 2013 and the seedlings development was evaluated at 30 days intervals until February 20th, 2014. The development parameters evaluated were plant height and stem diameter at $5 \mathrm{~cm}$ interval from the substrate surface. Three samples of each plant from each treatment were collected.

A randomized block design at $5 \times 3 \times 2$ factorial was used, where 5 level is the vermicompost or sewage sludge proportion $(0,25,50,75$, and $100 \%), 3$ is the number of times the biometric parameters were evaluated during the experiment (30,60, and 90 days after seedling, DAS), and 2 is the organic compound usage. A total of 48 replication for each treatment was used.

Initially, all data were tested with Shapiro-Wilk $(\mathrm{P}>0.01)$ and Levene $(\mathrm{P}>0.01)$ tests to evaluate the normality and homogeneity of the residual. After confirming data normality and homogeneity, or performing BOX-COX for missing/outline data transformation, they were tested by the Analysis of Variance test $(\mathrm{p} \leq 0.05)$ with unfolding of the quantitative effects in orthogonal polynomials, according to the F-test significance. The regression model was chosen from the higher significance level of F-test model that presented biologic behavior. The 
Statistical Analysis System (Sas institute, 2011) software was used for both Analysis of Variance and the regression model estimative.

\section{Results and Discussion}

Tables 1 and 2 show the chemical and heavy metal concentration for the sewage sludge used respectively, performed in duplicates. It is important to mention that the sewage sludge usage for any agriculture activity in Brazil must meet the Brasil (2006) regulation, which defines the maximum level of contaminants within its composition.

Table 3. Substrate chemical concentration for commercial (C), and for every vermicompost (V) and sewage sludge $(\mathrm{S})$ proportion used for red-angico and pink kapok seedling production

\begin{tabular}{|c|c|c|c|c|c|c|c|c|c|c|c|}
\hline Substrate & $\mathrm{pH}$ & $\begin{array}{c}\mathrm{P} \\
\cdots \cdot \mathrm{mg} \mathrm{d}\end{array}$ & $\begin{array}{c}\mathrm{K} \\
\mathrm{n}^{-3} \cdots\end{array}$ & $\begin{array}{c}\mathrm{Ca}^{2+} \\
\mathrm{cmol}_{\mathrm{c}} \mathrm{dm}^{-3}\end{array}$ & $\begin{array}{l}\text { Ntotal } \\
\text { dag } \mathrm{kg}^{-1}\end{array}$ & $\begin{array}{l}\mathrm{Mg}^{2+} \\
\ldots . \cdots \mathrm{c}\end{array}$ & $\begin{array}{c}\mathrm{Al}^{3+} \\
\operatorname{mol}_{\mathrm{c}} \mathrm{dr}\end{array}$ & $\begin{array}{l}\mathrm{H}+\mathrm{Al} \\
\mathrm{I}^{-3} \ldots \ldots \ldots\end{array}$ & $\begin{array}{c}\mathrm{EB} \\
\%\end{array}$ & $\begin{array}{c}\mathrm{BS} \\
\%\end{array}$ & $\begin{array}{c}\mathrm{OM} \\
\text { dag } \mathrm{kg}^{-1}\end{array}$ \\
\hline $\mathrm{C} 100$ & 5.2 & 528.7 & 462 & 5.7 & 0.18 & 2.9 & 0.1 & 5.0 & 9.8 & 66.1 & 27.6 \\
\hline $\mathrm{V} 25$ & 5.7 & 745.9 & 1249 & 6.5 & 0.15 & 5.3 & 0.1 & 4.0 & 15.0 & 78.9 & 25.0 \\
\hline V50 & 6.3 & 734.3 & 1369 & 6.0 & 0.18 & 7.1 & 0.0 & 4.1 & 16.6 & 80.2 & 22.5 \\
\hline V75 & 7.6 & 1322.7 & 3818 & 8.0 & 0.21 & 11.1 & 0.0 & 4.0 & 28.9 & 87.8 & 31.1 \\
\hline V100 & 7.0 & 4704.8 & 3754 & 8.1 & 0.21 & 12.7 & 0.1 & 2.1 & 30.4 & 93.5 & 27.6 \\
\hline $\mathrm{S} 25$ & 4.1 & 651.2 & 362 & 10.4 & 0.15 & 3.9 & 0.1 & 9.7 & 15.4 & 61.2 & 26.0 \\
\hline $\mathrm{S} 50$ & 4.7 & 725.1 & 302 & 13.0 & 0.15 & 4.4 & 0.1 & 9.7 & 18.2 & 65.2 & 28.8 \\
\hline S75 & 4.7 & 558.8 & 161 & 15.3 & 0.18 & 4.7 & 0.1 & 9.9 & 20.4 & 67.4 & 27.9 \\
\hline $\mathrm{S} 100$ & 5.7 & 1058.2 & 83 & 12.1 & 0.14 & 3.8 & 0.0 & 5.0 & 16.1 & 76.3 & 31.5 \\
\hline
\end{tabular}

*pH - pH in $\mathrm{H} 2 \mathrm{O}$; $\mathrm{P}$ - phosphor; $\mathrm{K}$ - potassium; $\mathrm{Ca}^{2+}$ - calcium; Ntotal - total nitrogen; $\mathrm{Mg}^{2+}$ magnesium; $\mathrm{Al}^{3+}$ - aluminum; $\mathrm{H}+\mathrm{Al}$ - exchangeable aluminum; $\mathrm{EB}$ - exchangeable base; $\mathrm{BS}$ percent base saturation; OM - organic matter. 
Table 4. Substrate heavy metal concentration for commercial (C), and for every vermicompost (V) and sewage sludge (S) proportion used for red-angico and pink kapok seedling production

\begin{tabular}{|c|c|c|c|c|c|c|c|c|}
\hline \multirow{2}{*}{ Substrate } & $\mathrm{Zn}$ & $\mathrm{Fe}$ & $\mathrm{Mn}$ & $\mathrm{Cu}$ & $\mathrm{Cd}$ & $\mathrm{Pb}$ & $\mathrm{Ni}$ & $\mathrm{Cr}$ \\
\hline & \multicolumn{8}{|c|}{$\mathrm{mg} \mathrm{dm}^{-3}$} \\
\hline $\mathrm{C} 100$ & 6.4 & 163.6 & 39.7 & 0.91 & 1.020 & 0.360 & 1.240 & 0.500 \\
\hline V25 & 18.2 & 116.1 & 79.2 & 0.61 & 0.980 & 0.460 & 0.980 & 0.530 \\
\hline V50 & 21.8 & 90.8 & 97.2 & 0.58 & 1.050 & 0.610 & 0.880 & 0.700 \\
\hline V75 & 39.2 & 46.5 & 198.9 & 0.54 & 0.800 & 0.670 & 0.550 & 0.640 \\
\hline V100 & 47.7 & 16.8 & 243.8 & 0.54 & 1.170 & 1.000 & 0.460 & 0.460 \\
\hline $\mathrm{S} 25$ & 84.3 & 259.9 & 39.8 & 5.76 & 1.260 & 0.320 & 1.270 & 0.500 \\
\hline $\mathrm{S} 50$ & 141.1 & 323.8 & 43.6 & 8.76 & 1.140 & 0.550 & 0.480 & 0.470 \\
\hline S75 & 180.1 & 382.6 & 49.5 & 14.67 & 0.980 & 0.800 & 0.630 & 0.440 \\
\hline $\mathrm{S} 100$ & 238.9 & 651.4 & 58.6 & 22.12 & 1.050 & 0.540 & 1.840 & 0.590 \\
\hline
\end{tabular}

*Zn - zinc; Fe - iron; $\mathrm{Mn}$ - manganese; $\mathrm{Cu}$ - copper; $\mathrm{Cd}$ - cadmium; $\mathrm{Pb}$ - lead; $\mathrm{Ni}$ - nickel; $\mathrm{Cr}$ - chrome.

After confirming data normality and homoscedasticity they were submitted to the statistic tests. Table 3 presents the regression analysis summary for red-angico plant height at 30, 60, and 90 DAS. It was observed a significative effect for plant height for all mixture tested at $1 \%$ level of probability. 
Table 3. Regression analysis summary by orthogonal polynomials for red-angico plant height at 30, 60, and 90 DAS for the different substrate composition

\begin{tabular}{|c|c|c|c|c|c|c|c|}
\hline \multirow{3}{*}{$\begin{array}{l}\text { Source of } \\
\text { variation }\end{array}$} & \multirow{3}{*}{$\mathrm{DF}$} & \multicolumn{6}{|c|}{ F-test } \\
\hline & & \multicolumn{3}{|c|}{ Vermicompost } & \multicolumn{3}{|c|}{ Sewage Sludge } \\
\hline & & 30 DAS & 60 DAS & 90 DAS & 30 DAS & 60 DAS & 90 DAS \\
\hline Linear & - & $6.21^{*}$ & $0.21^{\mathrm{ns}}$ & $1.12^{\mathrm{ns}}$ & $28.13^{* *}$ & $31.18^{* *}$ & $67.13^{* *}$ \\
\hline Quadratic & - & $317.46^{* *}$ & $328.92^{* *}$ & $415.34^{* *}$ & $80.18^{* *}$ & $69.03^{* *}$ & $71.91^{* *}$ \\
\hline Cubic & - & $1.71^{\mathrm{ns}}$ & $0.37^{\mathrm{ns}}$ & $0.01^{\mathrm{ns}}$ & $3.66^{\mathrm{ns}}$ & $3.43^{\mathrm{ns}}$ & $4.59^{\mathrm{ns}}$ \\
\hline Treatment & 4 & $87.19^{* *}$ & $83.07^{* *}$ & $104.49^{* *}$ & $29.61^{* *}$ & $26.44^{* *}$ & $38.33^{* *}$ \\
\hline $\mathrm{CV}(\%)$ & - & 23.87 & 27.24 & 27.07 & 27.44 & 22.39 & 20.96 \\
\hline RMSE & - & 1.79 & 2.58 & 3.06 & 1.84 & 1.53 & 1.35 \\
\hline Mean $(\mathrm{cm})$ & - & 7.54 & 9.47 & 11.31 & 6.63 & 10.69 & 13.08 \\
\hline
\end{tabular}

ns - not significant at 0.05 level of significance by F-test

* and ${ }^{* *}$ - significant at 0.05 and 0.01 level of significance, respectively, by F-test

DF - Degree of freedom; DAS - Days after seedling; CV (\%) - Coefficient of variance; RMSE - Root mean square error

Figure 1 shows the average values of plant height for the different vermicompost and sewage sludge concentrations at 30 (Figure 1A), 60 (Figure 1B), and 90 DAS (Figure 1C). All data were best represented by a quadratic curve for both mixtures and date of collection, with coefficient of determination $\left(\mathrm{R}^{2}\right)$ ranging from 0.9064 (for sewage sludge at $90 \mathrm{DAS}$ ) to 0.9905 (for vermicompost at $60 \mathrm{DAS}$ ). Maximum estimated values for red-angico plants height were observed for the substrate mixed with $75 \%$ of vermicompost (V75) for all periods evaluated, with $10.02,13.08$, and $16.14 \mathrm{~cm}$ for 30,60 , and $90 \mathrm{DAS}$, respectively. For all three evaluation, the $75 \%$ of sewage sludge (S75) treatment presented the highest plant height values of 8.03, 13.86 and $17.18 \mathrm{~cm}$, respectively at 30,60, and 90 DAS. Besides the lower values for S75 when compared to V75 (around $2 \mathrm{~cm}$ ) at 30 DAS, the increment of plants growth from the sewage sludge substrate treatment was higher at 90 DAS. In the last evaluation, the plant height for S75 treatment was $1.04 \mathrm{~cm}$ higher then V75, representing $6.4 \%$. 

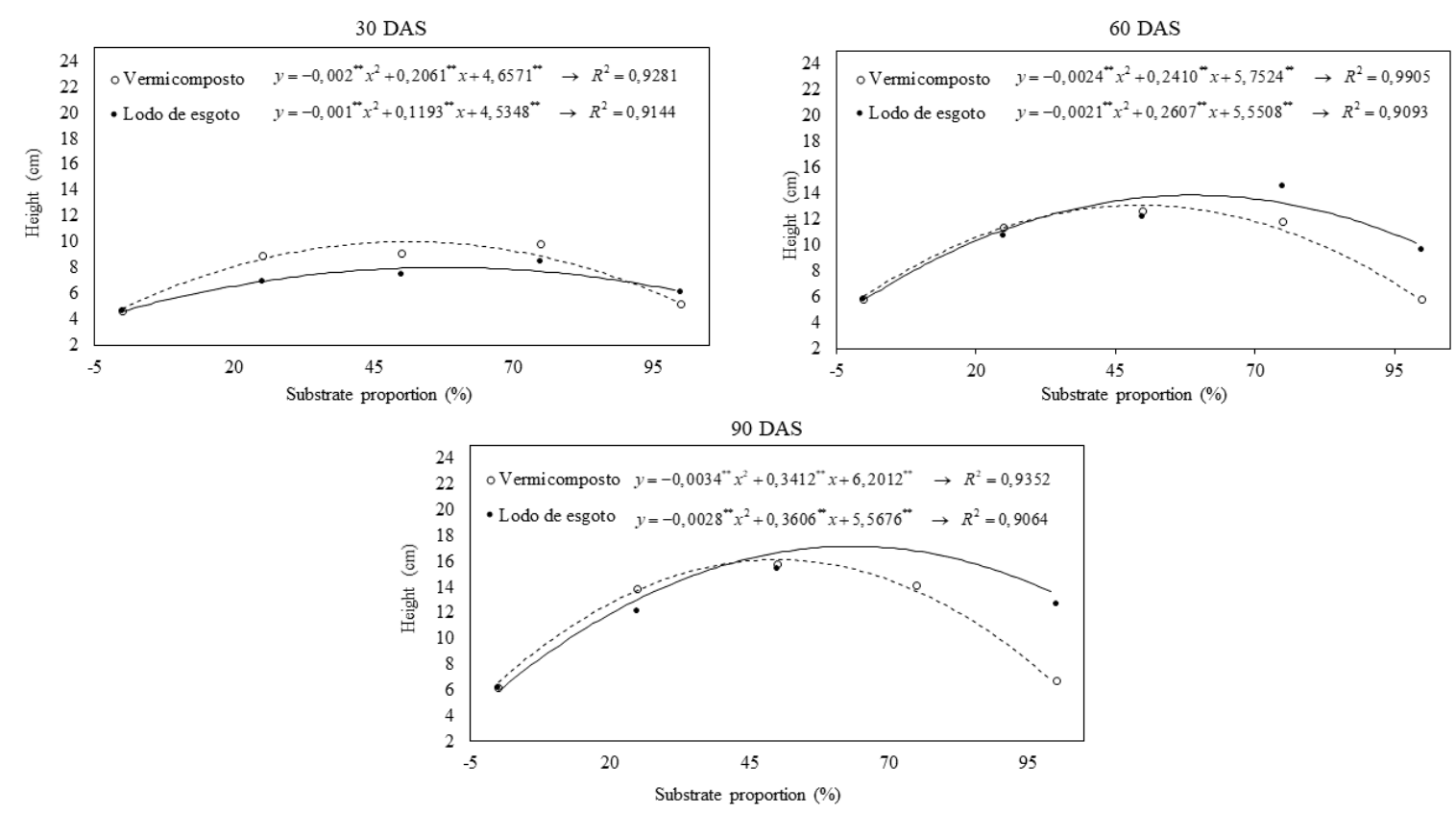

Figure 1. Scatter curves for red-angico plant height under different substrate proportion with vermicompost and sewage sludge

The results for the substrate with $100 \%$ of vermicompost or sewage sludge where lower than the $75 \%$ treatment, indicating that an increasing above $75 \%$ of both components to formulating the substrate might not be favorable for red-angico plant height parameter. In fact, the results from the V100/S100 and C100 treatments were alike and it can be an indicative that the use of only vermicompost or sewage sludge for seedling production can affect negatively the red-angico seedlings development. Therefore, mixing up to $75 \%$ of vermicompost and sewage sludge is recommended when plant height is the main parameter for high quality of red-angico seedlings production.

According to Silva et al. (2007), when commercial substrates are mixed to organic compounds such as vermicompost and sewage sludge they promotes an increment of the substrate density, reflecting on higher soil water holding capacity and lower soil porosity. Consequently, these effects will reduce the plant development due to the low plant root respiration and to the low root specific surface that is responsible for the nutrient uptake. Moreover, Oliveira (2011) mention that most of the organic-based substrates have low nutrient mineralization, which will retard the immediate nutrient intake. These affirmatives may be associated to the low red-angico plant height results obtained for V100 and S100 treatments.

Table 4 presents the regression analysis summary for red-angico plant stem diameter at 30, 60, and 90 DAS. It was observed a significative effect for this parameter for all substrate mixture tested at $1 \%$ level of probability. 
Table 4. Regression analysis summary by orthogonal polynomials for red-angico steam diameter at 30,60, and 90 DAS for the different substrate composition

Teste F

\begin{tabular}{cccccccc}
$\begin{array}{c}\text { Source of } \\
\text { Variation }\end{array}$ & DF & \multicolumn{3}{c}{ Vermicompost } & \multicolumn{3}{c}{ Sewage sludge } \\
\cline { 3 - 7 } & & 30 DAS & 60 DAS & 90 DAS & 30 DAS & 60 DAS & 90 DAS \\
\hline Linear & - & $37.73^{* *}$ & $9.24^{* *}$ & $2.98^{\mathrm{ns}}$ & $11.59^{* *}$ & $46.63^{* *}$ & $63.23^{* *}$ \\
Quadratic & - & $60.34^{* *}$ & $139.77^{* *}$ & $94.15^{* *}$ & $86.79^{* *}$ & $58.43^{* *}$ & $88.14^{* *}$ \\
Cubic & - & $3.62^{\mathrm{ns}}$ & $0.74^{\mathrm{ns}}$ & $0.01^{\mathrm{ns}}$ & $1.27^{\mathrm{ns}}$ & $0.10^{\mathrm{ns}}$ & $5.36^{*}$ \\
Treatment & 4 & $26.13^{* *}$ & $40.62^{* *}$ & $25.41^{* *}$ & $25.97^{* *}$ & $26.36^{* *}$ & $39.35^{* *}$ \\
\hline CV $(\%)$ & - & 12.62 & 15.56 & 23.35 & 11.69 & 19.14 & 20.00 \\
RMSE & - & 0.21 & 0.27 & 0.43 & 0.19 & 0.35 & 0.39 \\
Mean $(\mathrm{cm})$ & - & 1.66 & 1.74 & 1.84 & 1.58 & 1.81 & 1.97 \\
\hline
\end{tabular}

ns - not significant at 0.05 level of significance by F-test

* and ${ }^{* *}$ - significant at 0.05 and 0.01 level of significance, respectively, by F-test

DF - Degree of freedom; DAS - Days after seedling; CV (\%) - Coefficient of variance; RMSE - Root mean square error

Alike to red-angico plant height results presented in Figure 1, the values of stem diameter for all evaluations was best represented by a quadratic curve (Figure 2). $\mathrm{R}^{2}$ ranged from 0.9556 (vermicompost at $60 \mathrm{DAS}$ ) to 0.9530 (sewage sludge at 60 and $90 \mathrm{DAS}$ ) so the equations can be used on the stem diameter estimative for red-angico due to the proximity of $R^{2}$ to 1 . 

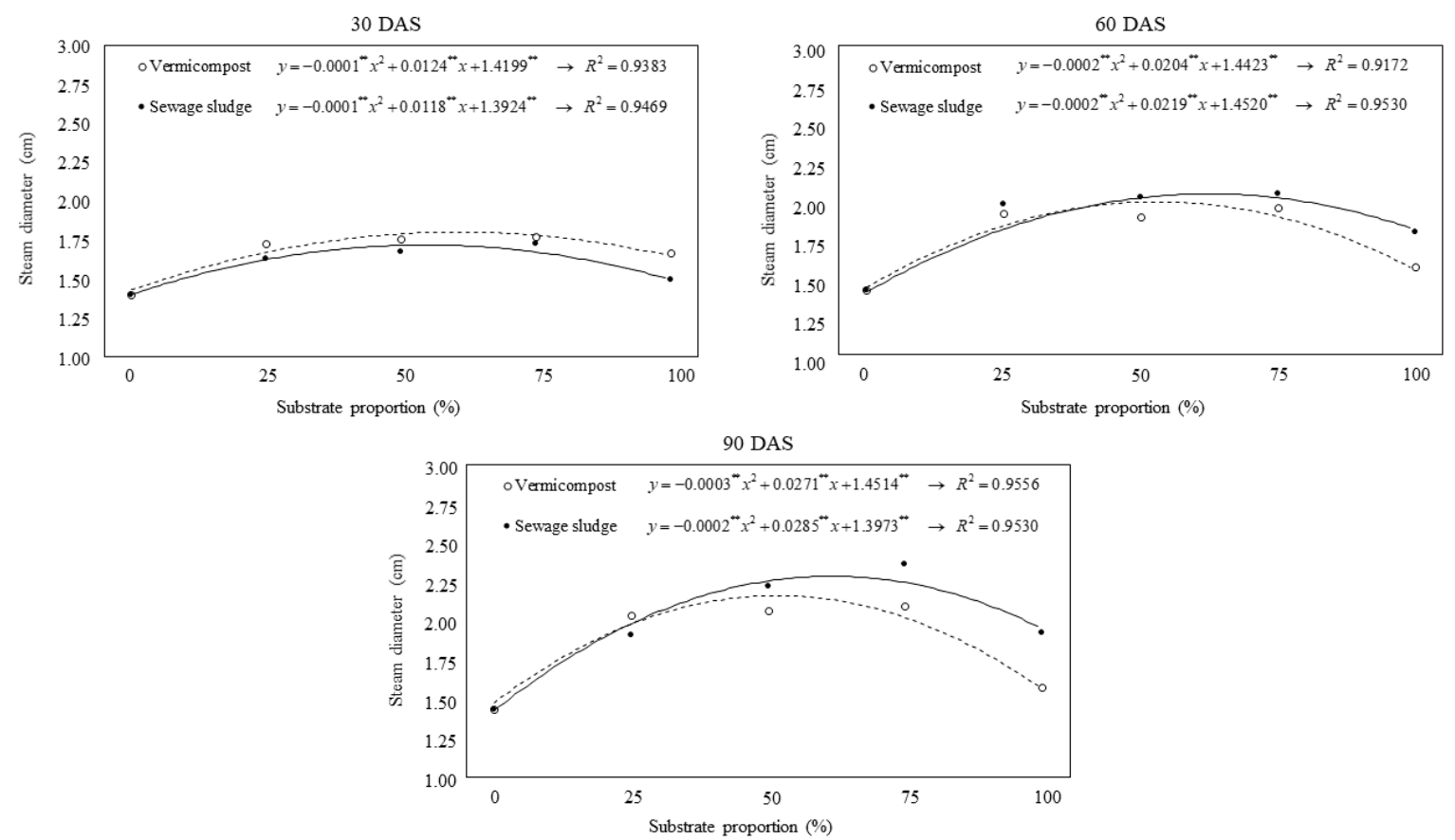

Figure 2. Scatter curves for red-angico steam diameter under different substrate proportion with vermicompost and sewage sludge

At 30 DAS, maximum estimated stem diameter for red-angico values were 1.80 and $1.72 \mathrm{~cm}$ for V50 and S75, respectively. While maximum estimated values were observed for V75 (1.99 $\mathrm{cm})$ and S50 $(2.04 \mathrm{~cm})$ at 60 DAS, for the third evaluation (90 DAS) the maximum stem diameter values were obtained for V50 and S75 treatments, with 1.99 and $2.29 \mathrm{~cm}$, respectively. Similar to what was observed for plant height, higher values of stem dimeter were also observed for the sewage sludge treatments compared to the vermicompost treatment. The S75 presented $0.3 \mathrm{~cm}$ increment of stem diameter over V50 at 90 DAS, which represents around $15 \%$ higher.

The performance of the substrate with $100 \%$ of vermicompost or sewage sludge treatments was also inferior when compared to $75 \%$ treatments for red-angico stem diameter, as already verified for red-angico plant height (Figure 1). These results show that using organic compounds leads to obtain high quality red-angico seedlings but only if they represent up to $75 \%$ of the total substrate composition. Higher proportion can cause reduction of plant development and it might be associated to the lower substrate physical characteristic.

Table 5 presents the regression analysis summary for pink kapok plant height at 30, 60, and 90 DAS. It was observed a significative effect for this parameter for all substrate mixture tested at $1 \%$ level of probability. 
Table 5. Regression analysis summary by orthogonal polynomials for pink kapok plant height at 30, 60, and 90 DAS for the different substrate composition

F-test

\begin{tabular}{cccccccc}
\cline { 3 - 7 } $\begin{array}{c}\text { Source of } \\
\text { Variation }\end{array}$ & DF & \multicolumn{3}{c}{ Vermicompost } & \multicolumn{3}{c}{ Sewage sludge } \\
\cline { 3 - 7 } & & 30 DAS & 60 DAS & 90 DAS & 30 DAS & 60 DAS & 90 DAS \\
\hline Linear & - & $117.54^{* *}$ & $412.42^{* *}$ & $619.69^{* *}$ & $144.24^{* *}$ & $144.07^{* *}$ & $347.86^{* *}$ \\
Quadratic & - & $4.75^{*}$ & $5.88^{*}$ & $8.51^{* *}$ & $29.68^{* *}$ & $129.76^{* *}$ & $193.45^{* *}$ \\
Cubic & - & $0.02^{\mathrm{ns}}$ & $0.01^{\mathrm{ns}}$ & $6.63^{*}$ & $0.26^{\mathrm{ns}}$ & $14.18^{* *}$ & $16.42^{* *}$ \\
Treatment & 4 & $30.59^{* *}$ & $105.14^{* *}$ & $158.87^{* *}$ & $44.27^{* *}$ & $72.64^{* *}$ & $140.32^{* *}$ \\
\hline CV $(\%)$ & - & 25.72 & 26.57 & 19.14 & 16.37 & 25.57 & 18.41 \\
RMSE & - & 8.84 & 7.71 & 8.94 & 3.29 & 8.93 & 9.27 \\
Mean (cm) & - & 22.28 & 29.03 & 46.71 & 20.07 & 34.91 & 50.34 \\
\hline
\end{tabular}

ns - not significant at 0.05 level of significance by F-test

* and ${ }^{* *}$ - significant at 0.05 and 0.01 level of significance, respectively, by F-test

DF - Degree of freedom; DAS - Days after seedling; CV (\%) - Coefficient of variance; RMSE - Root mean square error

Figure 3 shows the pink kapok plants height cultivated with different concentration of vermicompost and sewage sludge at 30,60, and 90 DAS. The best fit for the sewage sludge treatment found was a 2nd degree polynomial curve for all periods, the same what was observed for vermicompost treatment at 90 DAS. At 30 and 60 DAS, the best fit was a linear curve for vermicompost. Additionally, $\mathrm{R}^{2}$ were equal or higher than 0.9475 for all curves and, compared to the red-angico plant height (Figure 1) and stem diameter (Figure 2), even higher $\mathrm{R}^{2}$ for some periods. 

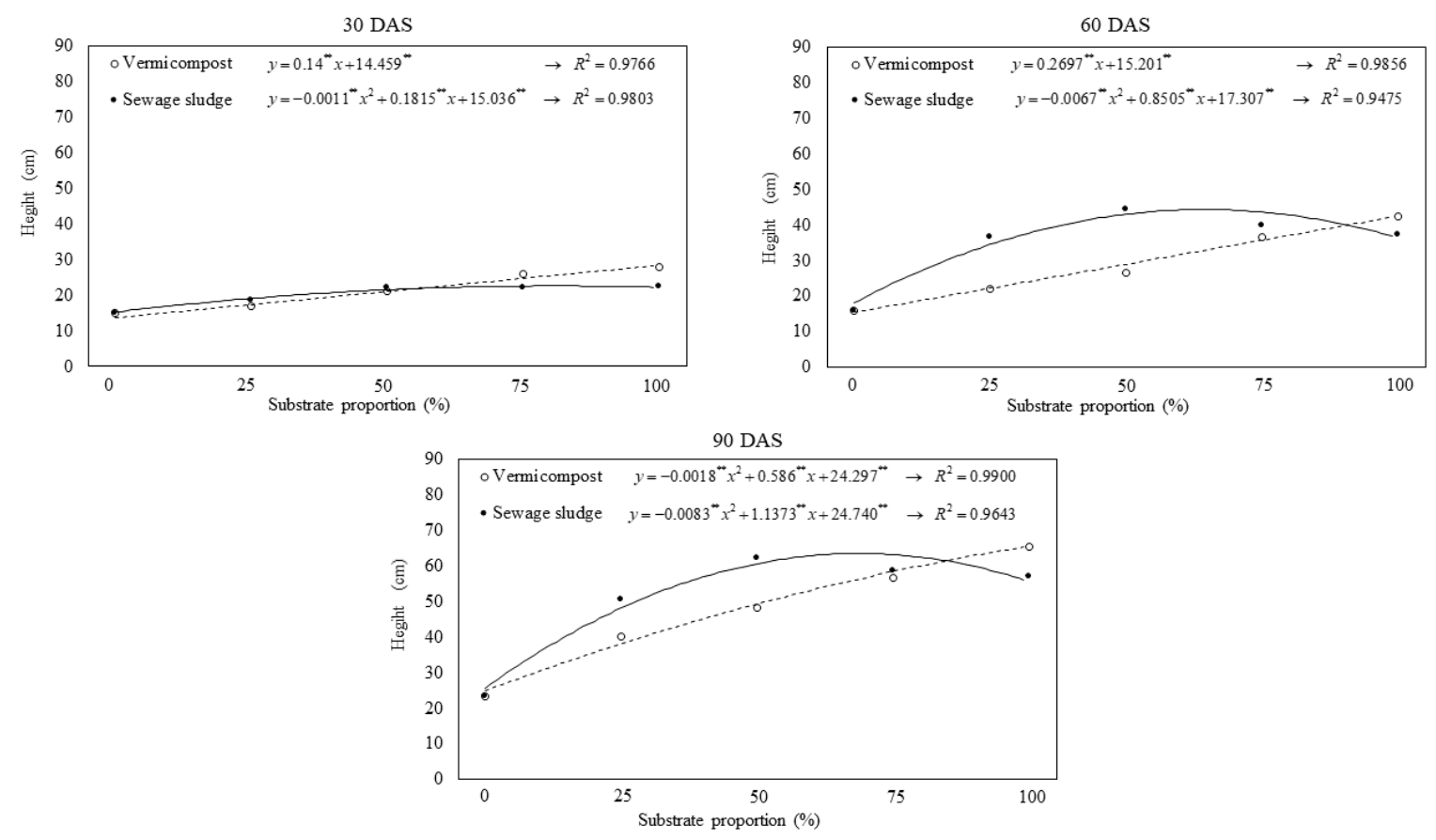

Figure 3. Scatter curves for pink kapok plant height under different substrate proportion with vermicompost and sewage sludge

The maximum estimated plant height was $28.26 \mathrm{~cm}$ for V100 at 30 DAS, which was about 5,6 $\mathrm{cm}$ higher than the $S 100(22.59 \mathrm{~cm})$ for the same period. At $60 \mathrm{DAS}$, although the maximum estimated value was also obtained for V100 with $42.17 \mathrm{~cm}$, highest estimated values was observed for the substrate with $50 \%$ of sewage sludge $(44.29 \mathrm{~cm})$. Similar results were found at 90 DAS, which the maximum estimated values were also observed for V100 and S50 treatment, with plant height of 65,29 and $63.43 \mathrm{~cm}$, respectively.

As also verified for red-angico plant height (Figure 1), the treatments with sewage sludge showed worst seedling development when compared to the vermicompost treatment for pink kapok at 30 DAS. However, the sewage sludge treatment also presented faster development from 30 to 90 DAS and overpassed the plant height values from vermicompost treatment. These results infer that sewage sludge can promote inadequate condition for red-angico and pink kapok seedlings at initial development, followed by an adequate condition as seedlings are better stablished.

Note that when sewage sludge represents $50 \%$ or higher of the substrate composition, negative effect for plants height was observed for both red-angico and pink kapok at 60 and 90 DAS (Figures 1 and 3). This fact supports the hypothesis that using higher proportion of sewage sludge on the substrate is not beneficial for forest seedling production, and the results can be even worse for substrate with $100 \%$ of this organic compound.

Table 6 presents the regression analysis summary for pink kapok stem diameter at 30,60, and 90 DAS. It was observed a significative effect for this parameter for all substrate mixture tested at $1 \%$ level of probability. 
Table 6 . Regression analysis summary by orthogonal polynomials for pink kapok steam diameter at 30,60, and 90 DAS for the different substrate composition

F-test

\begin{tabular}{cccccccc}
\cline { 3 - 6 } $\begin{array}{c}\text { Source of } \\
\text { Variation }\end{array}$ & DF & \multicolumn{3}{c}{ Vermicompost } & \multicolumn{3}{c}{ Sewage sludge } \\
\cline { 3 - 7 } & & 30 DAS & 60 DAS & 90 DAS & 30 DAS & 60 DAS & 90 DAS \\
\hline Linear & - & $70.73^{* *}$ & $19.01^{* *}$ & $25.05^{* *}$ & $0.28^{\mathrm{ns}}$ & $9.01^{* *}$ & $12.82^{* *}$ \\
Quadratic & - & $4.25^{*}$ & $1.96^{\mathrm{ns}}$ & $2.27^{\mathrm{ns}}$ & $4.53^{*}$ & $9.57^{* *}$ & $21.50^{* *}$ \\
Cubic & - & $1.63^{\mathrm{ns}}$ & $1.17^{\mathrm{ns}}$ & $1.13^{\mathrm{ns}}$ & $3.39^{\mathrm{ns}}$ & $1.86^{\mathrm{ns}}$ & $2.36^{\mathrm{ns}}$ \\
Treatment & 4 & $4.29^{* *}$ & $5.55^{* *}$ & $7.13^{* *}$ & $2.29^{\mathrm{ns}}$ & $2.86^{*}$ & $4.18^{* *}$ \\
\hline CV $(\%)$ & - & 37.77 & 31.73 & 33.23 & 32.39 & 27.31 & 30.70 \\
RMSE & - & 5.39 & 3.38 & 3.22 & 1.49 & 2.25 & 3.14 \\
Mean $(\mathrm{cm})$ & - & 6.19 & 7.50 & 8.82 & 4.58 & 7.16 & 8.69 \\
\hline
\end{tabular}

ns - not significant at 0.05 level of significance by F-test

* and ${ }^{* *}$ - significant at 0.05 and 0.01 level of significance, respectively, by F-test

DF - Degree of freedom; DAS - Days after seedling; CV (\%) - Coefficient of variance; RMSE

- Root mean square error

The observed data was best represented by a 2nd degree polynomial curve for the three evaluation periods for sewage sludge and only at 30 DAS for vermicompost, as shown in Figure 4. The best adjustment found for vermicompost treatment was a linear curve at 60 and 90 DAS. $\mathrm{R}^{2}$ ranged from 0.8919 (vermicompost at $30 \mathrm{DAS}$ ) to 0.99 (vermicompost at 90 DAS). 

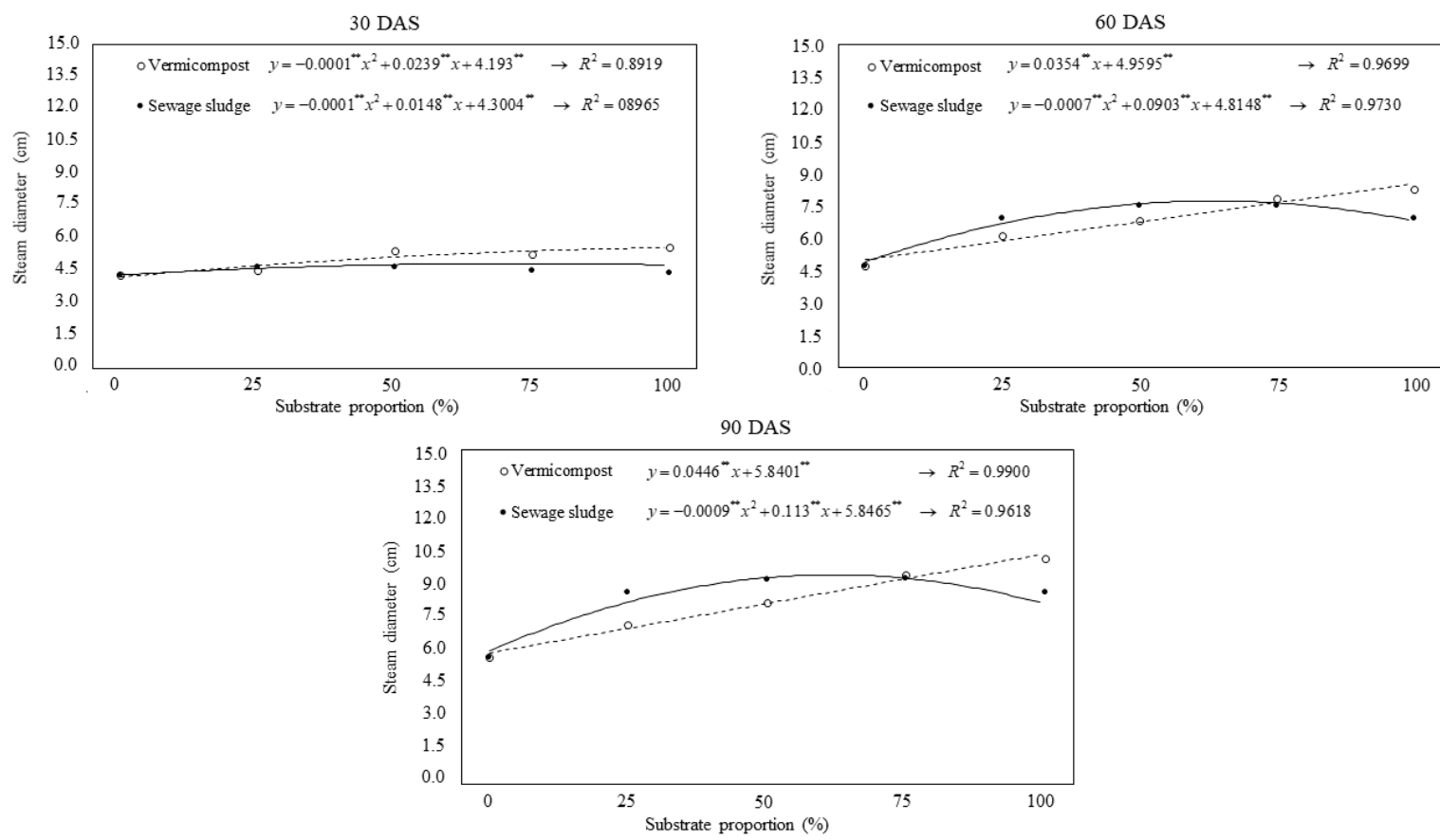

Figure 4. Scatter curves for pink kapok steam diameter under different substrate proportion with vermicompost and sewage sludge

As expected, the maximum estimated values for pink kapok stem diameter increased from first (30 DAS) to third evaluation (90 DAS) (Figure 4) and this can be explained due to the higher development period. Estimated maximum values were 5.58, 8.5, and $10.3 \mathrm{~cm}$ at 30,60 , and 90 DAS, respectively for V100. In the other hand, the estimated maximum of stem dimeter for sewage sludge was observed for S50, with values of 4.85, 7.79, and $9.39 \mathrm{~cm}$ at 30,60, and 90 DAS, respectively.

The stem diameter for S100 treatment have showed lower results for pink kapok when compared to S50 or S75, following the same results observed in Figures 1 to 3. These trends might be associated to (Santos et al., 2014) findings, which mention best forest seedling production when sewage sludge represents from 20 up to $80 \%$ of the total substrate composition.

Interestingly, worst red-angico seedlings performance was observed for those treatment cultivated with higher vermicompost within the substrate composition (above 75\%). These results show that red-angico seedlings might be more susceptible when only vermicompost is used to formulating the substrate. However, the V100 treatment did not influence the plant height and stem diameter for pink kapok and, in fact, this treatment presented the best results, indicating a high pink kapok adaptation to vermicompost. Similar results were found by Silva et al. (2017a), which substrates with $100 \%$ of vermicompost promoted higher plant height and stem diameter compared to other treatments $(20,40,60,80$ and $100 \%$ of vermiculite) for both red-angico and timbuáva (Enterolobium contortisiliquum (Vell.) Morong).

According to (Gomes et al., 1996), plant height ranging from $15-30 \mathrm{~cm}$ and stem dimeter 
higher than $2 \mathrm{~mm}$ are the seedlings classification parameters used by commercial production to indicate high seedling quality. The results presented in Figures 1 and 2 are within these parameters for red-angico plant height (V75 and S75) and stem diameter (V75, S50, and S75) at 90 DAS. For pink kapok, however, plant height was about 1.2 and 1.1 times higher for vermicompost and sewage sludge, respectively, and 4.2 and 4 times higher for stem diameter, respectively (Figures 3 and 4). These results demonstrate the benefits of mixing organic compound to the commercial substrate for forest seedling production, specially to red-angico which lower results than Gomes et al. (1996) suggested parameters were found for C100 treatments.

As already aforementioned, results about red-angico and pink kapok seedling production with vermicompost or sewage sludge are still lacking, preventing us to do a literature comparison. However, it is possible to affirm that the use of any organic compound has being showing promising results for forest seedling production. (Scheer et al., 2010) state that sewage sludge-based substrate with fertilization adding is a good alternative for monjoleiro (Parapiptadenia rigida (Benth.) Brenan) seedlings production, with similar plant height and stem diameter results when compared to the commercial substrate. For eucalyptus seedlings production, (Caldeira et al., 2013) observed better results for the substrate with $20 \%$ of sewage sludge and $80 \%$ of vermicompost, however, (Caldeira et al., 2013) describe that using organic compound did not promote benefits for aroeira-vermelha (Schinus terebinthifolius) seedling production to any organic compounds mixed to the commercial substrate. These conflicting results emphasize the importance of investigating the partial or total usage of organic compound on the substrate for every forest seedling production, so this could be used as an invaluable information for the adequate decision-making.

\section{Conclusion}

The use of vermicompost or sewage sludge as an alternative for red-angico and pink kapok seedling production was investigated. Adding these organic compounds to the commercial substrate promoted plant height and stem diameter increment for the forest species analyzed, with best results when they represented from 50 up to $75 \%$ of the substrate. The use of only commercial substrate did not promoted benefits to seedling developments, showing worst results then those treatments mixed with organic compound. However, the use of $100 \%$ of sewage sludge should be avoided since both red-angico and pink kapok showed worst seedlings development parameters results when compared to other treatments. The use of only vermicompost, otherwise, affected only the red-angico seedling production, showing the red-angico might be more sensible to both organic compounds analyzed.

\section{References}

Aquino, A. M., Oliveira, A. M. G., \& Loureiro, D. C. (2005). Integrando Compostagem e Vermicompostagem na Reciclagem de Resíduos Orgânicos Domésticos. Embrapa Agrobiol. 1-4.

Brasil, (2006). Resolução Conama n 375, de 29 de agosto de 2006. Define critérios e procedimentos, para o uso agrícola de lodos de esgoto gerados em estações de tratamento de 
esgoto sanitário e seus produtos derivados. Diário Oficial [da] República Federativa do Brasil.

Caldeira, M. V., Delarmelina, W. M., Peroni, L., Gonçalves, E., de. O., \& da Silva, A. G. (2013). Lodo de esgoto e vermiculita na produção de mudas de eucalipto. Pesqui. Agropecu. Trop. 43, 155-163. https://doi.org/10.1590/S1983-40632013000200002

Carvalho, D. F., de Silva, L. D. B. da., Folegatti, M. V., Costa, J. R., \& Cruz, F. A. da. (2006). Avaliação da evapotranspiração de referência na região de Seropédica-RJ, utilizando lisímetro de pesagem. Rev. Bras. Agrometeorol, 14, 108-116.

Chaves, L. de L. B., Carneiro, J. G. de A., \& Barroso, D. G. (2006). Crescimento de mudas de Anadenanthera macrocarpa (Benth) Brenan (angico -vermelho) em substrato fertilizado e inoculado com rizóbio. Rev. Árvore, 30, 911-919. https://doi.org/10.1590/S0100-67622006000600006

Gomes, J. M., Paiva, H. N., \& Couto, L. (1996). Produção de mudas de eucalipto. Inf. Agropecuário, 18, 15-22.

Gonzaga, M. I. S., Mackowiak, C., de Almeida, A. Q., \& Júnior, J. I. T., de C. (2018). Sewage sludge derived biochar and its effect on the growth and morphological traits of eucalyptus grandis W. Hill ex maiden seedlings. Cienc. Florest., 28, 687-695. https://doi.org/10.5902/1980509832067

Oliveira, E. A. G. (2011). Desenvolvimento de substratos orgânicos , com base na vermicompostagem, para produção de mudas de hortaliças em cultivo protegido. Universidade Federal Rural do Rio de Janeiro.

Peel, M. C., Finlayson, B. L., \& McMahon, T. A. (2007). Updated world map of the Köppen-Geiger climate classification. Hydrol. earth Syst. Sci. Discuss., 11, 1633-1644. https://doi.org/10.5194/hess-11-1633-2007

Rocha, J. H. T., Backes, C., Diogo, F. A., Pascotto, C. B., \& Borelli, K. (2013). Composto de lodo de esgoto como substrato para mudas de eucalipto. Pesqui. Florest. Bras., 33, 27-35. https://doi.org/10.4336/2013.pfb.33.73.331

Santos, F. E. V., Kunz, S. H., Caldeira, M. V. W., Azevedo, C. H. S., \& Rangel, O. J. P. (2014). Características químicas de substratos formulados com lodo de esgoto para produção de mudas florestais. Rev. Bras. Eng. Agrícola e Ambient., 18, 971-979. https://doi.org/10.1590/1807-1929/agriambi.v18n09p971-979

Sas Institute. (2011). Introduction to Statistical Modeling with SAS/ STAT Software. SAS/STAT 9.3 User's Guid.

Scheer, M. B., Carneiro, C., \& Santos, K. G. (2010). Substratos à base de lodo de esgoto compostado na produção de mudas de Parapiptadenia rigida ( Benth .). Sci. For., 38, 637-644.

Silva, R. F., da De Marco, R., Almeida, H. S., \& de Grolli, A. L. (2017). Proporções de vermicomposto e vermiculita na produção de mudas de timbaúva e angico-vermelho. Holos, 8 , 32. https://doi.org/10.15628/holos.2017.4607 


\section{Macrothink}

Silva, S. S., Araújo Neto, S. E., Kusdra, J. F., \& Ferreira, R. L. F. (2007). Produção orgânica de mudas de couve-manteiga em substratos à base de coprólito de minhocas. Caatinga, 20, 78-83.

Toledo, F. H. S. F., de Venturin, N., Carlos, L., Dias, B. A. S., Venturin, R. P., \& Macedo, R. L. G. (2015). Composto de resíduos da fabricação de papel e celulose na produção de mudas de eucalipto. Rev. Bras. Eng. Agrícola e Ambient., 19, 711-716. https://doi.org/10.15628/holos.2017.4607

Uliana, M. B., Fey, R., Malavasi, M. M., \& Malavasi, U. C. (2014). Produção de mudas de Anadenanthera macrocarpa em função de substratos alternativos e da frequência de fertirrigação. Floresta, 44, 303-312. https://doi.org/10.5380/rf.v44i2.31412

\section{Copyright Disclaimer}

Copyright for this article is retained by the author(s), with first publication rights granted to the journal.

This is an open-access article distributed under the terms and conditions of the Creative Commons Attribution license (http://creativecommons.org/licenses/by/4.0/). 